\title{
Ethanol Inhibits Kainate Responses of Glutamate Receptors Expressed in Xenopus Oocytes: Role of Calcium and Protein Kinase C
}

\author{
J. E. Dildy-Mayfield' ${ }^{1}$ and R. A. Harris ${ }^{1,2}$ \\ ${ }^{1}$ Department of Pharmacology, University of Colorado Health Sciences Center, Denver, Colorado 80262 and \\ ${ }^{2}$ Department of Veterans Affairs Medical Center, Denver, Colorado 80220
}

Recombinant $\alpha$-amino-3-hydroxy-5-methyl-4-isoxazole propionic acid (AMPA)/kainate receptors expressed in oocytes are inhibited by ethanol and the sensitivity to ethanol depends on the kainate concentration and the subunit(s) expressed. For example, GluR3 kainate channels are more sensitive to inhibition by ethanol than GluR6 channels in the presence of maximally effective kainate concentrations. To determine if the ethanol inhibition was influenced by the cation permeability $\left(\mathrm{Na}^{+}\right.$vs $\mathrm{Na}^{+}$and $\left.\mathrm{Ca}^{2+}\right)$ of the channels expressed, we compared ethanol inhibition of $\mathrm{Ca}^{2+}$-permeable glutamate receptors (GluRs) in oocytes perfused with normal- and high- $\mathrm{Ca}^{2+}$ buffers. The ethanol inhibition was much greater when $\mathrm{Ca}^{2+}$ was the only permeant cation. When $\mathrm{Ba}^{2+}$ was substituted for $\mathrm{Ca}^{2+}$, the ethanol inhibition was reduced, although it was still greater than with normal buffer. The enhanced ethanol inhibition of kainate-stimulated $\mathrm{Ca}^{2+}$ currents was reduced in oocytes injected with the $\mathrm{Ca}^{2+}$ chelator BAPTA, suggesting a role for intracellular $\mathrm{Ca}^{2+}$ in mediating enhanced ethanol sensitivity of kainate channels. The enhanced ethanol inhibition of $\mathrm{Ca}^{2+}$ currents was not due to a direct ethanol inhibition of $\mathrm{Ca}^{2+}$-stimulated $\mathrm{Cl}^{-}$currents in the oocyte because ethanol produced no effect on $\mathrm{Ca}^{2+}$-stimulated $\mathrm{Cl}^{-}$ currents induced by injection of myo-inositol-1,4,5-trisphosphate. Because $\mathrm{Ca}^{2+}$ activates protein kinase $\mathrm{C}$ (PKC) and because we found that the PKC activator phorbol 12myristate 13-acetate inhibits kainate responses (Dildy-Mayfield and Harris, 1994), we examined the role of PKC in mediating the enhanced ethanol inhibition of kainate responses produced by increased $\mathrm{Ca}^{2+}$. Inhibition of PKC by injection of the PKC inhibitor peptide or calphostin $C$ prevented the enhanced ethanol inhibition of kainate-induced $\mathrm{Ca}^{2+}$ responses without altering ethanol inhibition in normal buffer. Thus, ethanol inhibition of kainate channels may involve two mechanisms, one that is independent of PKC and a second type that is due to activation of PKC under conditions of elevated $\mathrm{Ca}^{2+}$, resulting in enhanced inhibition of kainate responses.

\footnotetext{
Received Sept. 7, 1994; revised Nov. 10, 1994; accepted Nov. 17, 1994.

We thank J. Boulter and S. Heinemann (The Salk Institute) for kindly providing GluR cDNA. This work was supported by the Department of Veterans Affairs, NIAAA Grant AA06399, and National Research Service Award AA05334 to J.E.D.-M.

Correspondence should be addressed to Dr. J. E. Dildy-Mayfield, Department of Pharmacology, Box C236, University of Colorado Health Sciences Center 1200 E. Ninth Avenue, Denver, CO 80262.

Copyright $\odot 1995$ Society for Neuroscience $0270-6474 / 95 / 153162-10 \$ 05.00 / 0$
}

[Key words: AMPA, kainate, glutamate receptor, Xenopus oocyte, ethanol, $\left.\mathrm{Ca}^{2+}, \mathrm{PKC}\right]$

Several glutamate receptor (GluR) subunits have been cloned that express functional homomeric or heteromeric channels gated by $\alpha$-amino-3-hydroxy-5-methyl-4-isoxazole propionic acid (AMPA), kainate, quisqualate, or glutamate but not $N$-methylD-aspartate (NMDA) (see Sommer and Seeburg, 1992, for review). These proteins are grouped into three different families of ionotropic receptors based on differences in their primary structures and functional characteristics. GluR $1-4$ subunits represent one family of rat glutamate receptors designated as AMPA receptors based on high-affinity AMPA binding, although kainate is a more efficacious agonist at channels formed by these subunits. When GluR1, GluR3, or GluR $1+3$ receptors are expressed in Xenopus oocytes, the channels show inward rectification and $\mathrm{Ca}^{2+}$ permeability in response to kainate stimulation (Boulter et al., 1990; Nakanishi et al., 1990; Hollmann et al., 1991). Before this finding, non-NMDA channels were believed to be impermeable to $\mathrm{Ca}^{2+}$, although a type of $\mathrm{Ca}^{2+}$ permeable kainate response was observed in vivo in rat hippocampal neurons (lino et al., 1990; Ozawa et al., 1991). Expression of the GluR2 subunit alone produces very small currents, but coexpression with GluR1 or GluR3 subunits results in responses that are larger than those produced by GluR1 or GluR3 alone. In addition, GluR2 expressed in combination with GluR1 or GluR3 gives a linear $I-V$ relationship with no $\mathrm{Ca}^{2+}$ permeability (Boulter et al., 1990; Nakanishi et al., 1990; Hollmann et al., 1991). A positively charged arginine residue in the second transmembrane region of the GluR2 protein is responsible for its lack of $\mathrm{Ca}^{2+}$ permeability, and GluR1 and GluR3 have a neutral glutamine residue in this position (Hume et al., 1991; Mishina et al., 1991). GluR5-7 subunits comprise a second family of rat kainate-sensitive glutamate receptors. The GluR5 and GluR7 subunits show little or no channel activity when expressed alone (Bettler et al., 1990; Bettler et al., 1992), but GluR6 subunits form homomeric channels that are highly sensitive to kainate but not. AMPA (Fgehjerg et al., 1991). Posttranscriptional modifications of certain GluR transcripts may be generated by RNA editing (Sommer et al., 1991), and the level of RNA editing of GluR6 transcripts determines the level of $\mathrm{Ca}^{2+}$ permeability (Egebjerg and Heinemann, 1993; Köhler et al., 1993). The third family of glutamate receptors includes the subunits KA-1 and KA-2 that are high-affinity kainate receptors but do not form functional homomeric channels (Werner et al., 1991; Herb et al., 1992). 
Ethanol inhibits glutamate receptor function, and previous studies suggested that this inhibition is greater for NMDA than non-NMDA receptor-operated channels (Hoffman et al., 1989; Lovinger et al., 1989). However, we reported that non-NMDA (kainate/AMPA) channels expressed in Xenopus oocytes from rat brain mRNA were also sensitive to ethanol inhibition, and the ethanol sensitivity of some non-NMDA responses was similar to that obtained with NMDA (Dildy-Mayfield and Harris, 1992). Responses produced by low concentrations of kainate were more sensitive to inhibition by ethanol than were responses produced by high kainate concentrations. This differential inhibition by ethanol could not be attributed to a competitive interaction at the kainate receptor or to differences in the magnitude of current responses produced by different kainate concentrations, suggesting that subtypes of brain kainate receptors were expressed with differing sensitivities to ethanol. We provided initial evidence that ethanol inhibits kainate responses of GluR3expressing oocytes (Dildy-Mayfield et al., 1991) that agrees with recent work by Lovinger (1993) showing that other AMPA subunits from the GluR1-4 family are also ethanol sensitive.

The above studies indicate that ethanol can inhibit AMPA/ kainate receptor function, suggesting that ethanol actions on glutamate receptors may not be selective for NMDA subtypes as proposed originally and that further study of ethanol's action on AMPA/KA subunits is warranted. To determine if ethanol can differentially affect subtypes of AMPA/kainate receptors as has been reported for different NMDA clones (Koltchine et al., 1993; Masood et al., 1994), we expressed GluR clones from two different families of GluRs in Xenopus oocytes and compared ethanol's action on homo- and heteromeric subtypes of kainatesensitive channels. We then examined potential mechanisms for the differential ethanol inhibition depending on subunit composition by determining if ethanol sensitivity was influenced by the cation permeability $\left(\mathrm{Ca}^{2+}\right.$ vs $\left.\mathrm{Na}^{+} / \mathrm{Ca}^{2+}\right)$ of the channels expressed. A common mechanism for ethanol action on several different types of ionotropic and metabotropic receptors has been suggested to be due to activation of protein kinase $\mathrm{C}$ (PKC) (Wafford and Whiting, 1992; Sanna et al., 1994; Snell et al., 1994). PKC-dependent receptor phosphorylation of GluRs has been demonstrated (McGlade-McCulloh et al., 1993), and we reported that $\mathrm{PKC}$ activation can also modulate kainate receptor function of GluRs (Dildy-Mayfield and Harris, 1994). In the present study, we examined the potential role of PKC in modulating ethanol inhibition of kainate responses.

\section{Materials and Methods}

GluR1, -R2, and -R3 cDNA (flop splice variants) in Bluescript SKand GluR6 cDNA were kindly provided by J. Boulter and S. Heinemann (Salk Institute). Ultracomp Escherichia coli transformation kit was from Invitrogen (San Diego, CA). The Qiagen kit was used for purification of plasmid cDNA (Chatsworth, CA). Rat brain mRNA and GluR cRNA were prepared using the Fast Track kit (Invitrogen, San Diego, CA) and the Stratagene mCAP mRNA capping kit (La Jolla, CA), respectively. Adult Xenopus laevis female frogs were purchased from Xenopus I (Ann Arbor, MI). Kainate, ethyleneglycol-bis-( $\beta$-aminoethylether)$N, N, N^{\prime}, N^{\prime}$-tetraacetic acid (EGTA), 1,2-bis(2-aminophenoxy)ethane$N, N, N^{\prime}, N^{\prime}$-tetraacetic acid (BAPTA), phorbol 12-myristate 13-acetate (PMA), concanavalin A (type IV), collagenase type 1A, and other reagents were purchased from Sigma Chemical Co. (St. Louis, MO). The protein kinase C inhibitor peptide [PKC (19-36)] was from GIBCO (Grand Island, NY), and calphostin $\mathrm{C}$ and myo-inositol-1,4,5-trisphosphate $\left(\mathrm{IP}_{3}\right)$ were from Calbiochem (La Jolla, CA).

GluR cRNA/brain mRNA preparation. GluR1-3 cDNA in pBluescript $\mathrm{SK}^{-}$were transformed and amplified in $E$. coli, purified according to the Qiagen protocol, linearized with Xho I, proteinase K treated, phenol- chloroform extracted, and ethanol precipitated in sodium acetate. RNA was prepared using the Stratagene Iranscription kil with T3 as the polymerase. The cRNA was then phenol-chloroform extracted and ethanol precipitated in sodium acetate. Prior to injection, an aliquot of the cRNA was centrifuged for $15 \mathrm{~min}$ at $13,000 \times \mathrm{g}$. Rat brain mRNA was isolated as described previously (Dildy-Mayfield and Harris, 1992).

Isolation and injection of Xenopus oocytes. Oocytes were dissected manually and collagenase treated prior to injection (Dildy-Mayfield and Harris, 1992). Oocytes were injected with either (1) 10-20 ng GluR1, (2) 10-20 ng R3, (3) 10-20 ng R1 + 10-20 ng R3, (4) $50 \mathrm{ng} \mathrm{R} 2+$ 10 ng R3 cRNA, (5) $50 \mathrm{ng} \mathrm{R} 2$ + $10 \mathrm{ng} \mathrm{R} 1+10 \mathrm{ng} \mathrm{R} 3$, (6) $5 \mathrm{ng}$ R6 cDNA, or (7) 100 ng rat brain mRNA. RNA or DNA was resuspended in diethyl pyrocarbonate-treated water, and a digital microdispenser was used for injections. Oocytes were either impaled in the vegetal pole near the equator for cytoplasmic injections of RNA (GluR1-3 cRNA or brain mRNA) or in the animal pole for nuclear injections of GluR6 cDNA according to the blind method of Colman (1984). Injection volumes were 30 and $50 \mathrm{nl}$ for nuclear and cytoplasmic injections, respectively. Oocytes were cultured at $16^{\circ} \mathrm{C}$ in filter-sterilized modified Barth's solution [MBS; containing, in $\mathrm{mM}, \mathrm{NaCl}, 88 ; \mathrm{KCl}, 1 ; \mathrm{NaHCO}_{3}, 2.4$; HEPES, 10; $\left.\mathrm{MgSO}_{4}, 0.82 ; \mathrm{Ca}\left(\mathrm{NO}_{3}\right)_{2}, 0.33 ; \mathrm{CaCl}_{2}, 0.91 ; \mathrm{pH} 7.5\right]$ supplemented with $10 \mathrm{mg} / \mathrm{liter}$ streptomycin, $10,000 \mathrm{U} /$ liter penicillin $\mathrm{G}$, $50 \mathrm{mg} / \mathrm{liter}$ gentamicin, $0.5 \mathrm{~mm}$ theophylline, and $2 \mathrm{~mm}$ sodium pyruvate) and used on days $1-12$ after injection.

Whole-cell voltage clamp of injected oocytes. Oocytes were placed in a rectangular $100 \mu \mathrm{l}$ recording chamber and perfused with MBS or the various Ringer solutions at a rate of $2 \mathrm{ml} / \mathrm{min}$ at room temperature. Recording and clamping electrodes (1-5 M $\Omega$ ) were pulled from 1.2 $\mathrm{mm}$ outside diameter capillary tubing, filled with $3 \mathrm{M} \mathrm{KCl}$, and impalcd into the oocyte animal pole. An Axoclamp-2 current and voltage clamp (Axon Instruments, Burlingame, CA) or Warner oocyte clamp (Warner Instr. Corp., Hamden, $\mathrm{CN}$ ) was used for voltage clamping each oocyte at $-70 \mathrm{mV}$.

Experimental conditions. Initial experiments were performed using MBS (see above) as the buffer. For $\mathrm{Ca}^{2+}$ permeability studies, frog Ringer (containing, in $\mathrm{mM}, \mathrm{NaCl}, 115 ; \mathrm{KCl}, 2.5 ; \mathrm{CaCl}_{2}, 1.8 ; \mathrm{HEPES}$, 10 ; $\mathrm{pH}$ adjusted to 7.2 with $\mathrm{NaOH}$ ), $\mathrm{Na}^{+} / \mathrm{K}^{+}$-free Ringer (normal Ringer with $\mathrm{NaCl}$ and $\mathrm{KCl}$ isoosmotically substituted with $N$-methyl-D-glucamine, $\mathrm{pH}$ adjusted to 7.2 with $\mathrm{HCl}$ ), or $\mathrm{Ca}^{2+} \mathrm{Ringer}\left(\mathrm{Na}^{+} / \mathrm{K}^{+}\right.$-free Ringer containing $10 \mathrm{mM} \mathrm{CaCl}$ ) was used (Hollmann et al., 1991). EGTA $(6 \mathrm{~mm})$ and BAPTA $(20 \mathrm{~mm})$ stock solutions were prepared in water, $\mathrm{pH}$ adjusted to 7.4, and final concentrations (assuming an oocyte volume of $1 \mu \mathrm{l}$ ) of $100-500 \mu \mathrm{M}$ were injected during or before recording as indicated (the injection volume did not exceed $25 \mathrm{nl}$ ). Two control $\mathrm{IP}_{3}$ injections (using a $10 \mu \mathrm{M}$ stock solution) were tested to ensure that the responses were stable before testing the effects of $100 \mathrm{~mm}$ ethanol bath perfusion on $\mathrm{IP}_{3}$-induced currents. Ethanol was applied for approximalely 30 sec before $I_{3}$ injection and perfused continuously until the $\mathrm{IP}_{3}$-induced current reached a steady state level. At least $20 \mathrm{~min}$ after responses returned to baseline was allowed between $\mathrm{IP}_{3}$ injections. The PKC inhibitor peptide [PKC (19-36)] was stored frozen in water, and $300 \mathrm{ng} / 15 \mathrm{nl}$ was injected before or during recording. PMA and calphostin C were stored frozen in dimethyl sulfoxide (DMSO); $50 \mathrm{nM}$ PMA in MBS (0.1\% DMSO final concentration) was perfused for $5 \mathrm{~min}$ during recording and a final concentration of $1 \mu \mathrm{M}$ calphostin $\mathrm{C}$ diluted in water was injected before recording. The PKC inhibitor peptide or calphostin $\mathrm{C}$ was injected approximately $60 \mathrm{~min}$ before recording in $\mathrm{Ca}^{2+}$ Ringer. For GluR6-injected oocytes, $10 \mu \mathrm{M}$ concanavalin A in MBS was preapplied for up to 5 min to prevent desensitization (Egebjerg et al., 1991; Sakimura et al., 1992). Kainate was prepared in either MBS or the various Ringer solutions and was bath perfused for 15-60 sec depending on the GluR subunit studied. Ethanol was preapplied for $30-60 \mathrm{sec}$ before perfusion with kainate solutions containing ethanol Drug responses were typically measured every 5-10 min with up to 20 min intervals allowed when measuring $\mathrm{Ca}^{2+}$ currents.

Data analysis. Each oocyte represents a single $n$, and oocytes from at least two different frogs were tested for each experimental condition. Current responses (in $\mathrm{nA}$ ) were expressed as a percentage of control due to variability in expression among oocytes. Control kainate responses were measured before and after ethanol + kainate responses and averaged. Data were analyzed by analysis of variance followed by Student-Newman-Keuls post hoc tests. Concentration-response curves were fit and analyzed using ALLFIT. 


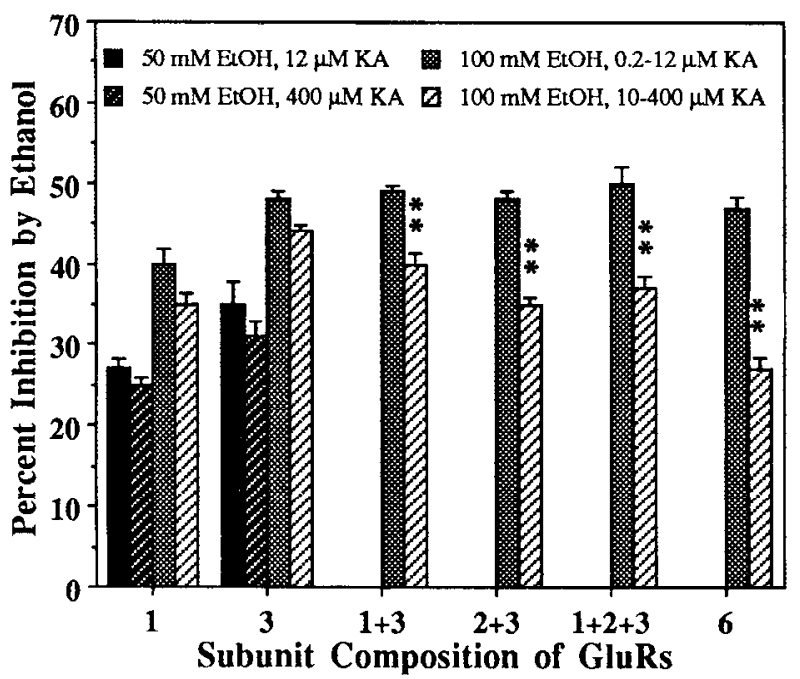

Figure 1. Ethanol inhibits kainate responses in oocytes expressing homomeric and heteromeric GluR subunits. Kainate $(K A)$ concentrations used for GluR1-3 injected oocytes were 12 and $400 \mu \mathrm{M}$, whereas the concentrations used for GluR6-injected oocytes were 0.2 and 10 $\mu \mathrm{M}$. Ethanol $(E t O H)$ concentrations were 50 and $100 \mathrm{~mm}$. Values represent mean $\left(+\right.$ SEM) percentage inhibition by ethanol $(n=6-32)$. ${ }^{* *}$, $p<0.01$ compared to 0.2 or $12 \mu \mathrm{M}$ kainate.

\section{Results}

Effect of ethanol on kainate-induced currents in recombinant GluRs

The effects of ethanol on kainate-induced currents were examined in oocytes expressing homo- or heteromeric GluR subunits. We initially studied minimally and maximally effective concentrations of kainate because our previous work with rat brain mRNA-injected oocytes demonstrated that inhibition by ethanol decreased as the kainate concentration increased (Dildy-Mayfield and Harris, 1992). In oocytes expressing GluR3 receptors, $50 \mathrm{~mm}$ ethanol inhibited 12 and $400 \mu \mathrm{M}$ kainate-induced currents by $35 \%$ and $31 \%$, respectively, and $100 \mathrm{~mm}$ ethanol produced $48 \%$ and $44 \%$ inhibition (Fig. 1). Ethanol inhibition was reversible, and desensitization of $400 \mu \mathrm{M}$ kainate responses was typically observed in oocytes expressing GluR3 or GluR1+3 receptors (see Fig. 3A). This type of slow desensitization of $\mathrm{Ca}^{2+}$-permeable receptors was not due to activation of endogenous $\mathrm{Ca}^{2+}$-dependent $\mathrm{Cl}^{-}$currents in the oocyte because it was not affected by injection of EGTA or BAPTA (see Fig. 3B). This is in agreement with Dawson et al. (1990), who reported a desensitization of kainate currents of GluR 1 receptors expressed in oocytes that was not due to activation of $\mathrm{Ca}^{2+}$-dependent $\mathrm{Cl}^{-}$ currents.

Ethanol inhibition of GluR3 kainate responses was also constant across a 200-fold concentration range (i.e., $100 \mathrm{~mm}$ ethanol similarly inhibited $5 \mu \mathrm{M}$ and $1 \mathrm{mM}$ kainate-induced currents by $44 \pm 1.0 \%$ and $42 \pm 0.5 \%$, respectively). Ethanol inhibition of homomeric GluR 1 receptors was also independent of the kainate concentration (Fig. 1).

We next studied ethanol inhibition of kainate responses of heteromeric combinations of GluR subunits. Responses to 12 and $400 \mu \mathrm{M}$ kainate were inhibited $49 \%$ and $40 \%$, respectively, by $100 \mathrm{~mm}$ ethanol in oocytes expressing GluR $1+3$ subunits (Fig. 1). GluR2+3-expressing oocytes demonstrated differential sensitivity to ethanol in that $12 \mu \mathrm{M}$ kainate responses were more sensitive to ethanol inhibition $(48 \%)$ than $400 \mu \mathrm{M}$ kainate re- sponses (35\%) (Fig. 1). Nondesensitizing kainate currents, similar to those obtained when expressing brain mRNA, were typically observed in oocytes expressing GluR $2+3$ subunits. Coexpression of the GluR2 subunit was verified by demonstrating that these channels were not $\mathrm{Ca}^{2+-}$-permeable while channels formed from GluR3 receptors alone were permeable to $\mathrm{Ca}^{2+}$ (see Hollmann et al., 1991). Ethanol inhibition also depended upon the kainate concentration in oocytes expressing GluR1+2+3 subunits (Fig. 1).

The GluR6 receptor was much more sensitive to kainate than the GluR $1-3$ receptors with $10 \mu \mathrm{M}$ kainate producing a maximal response (in agreement with Egebjerg et al., 1991). As reported previously (Egebjerg et al., 1991; Sakimura et al., 1992), concanavalin A blocked desensitization and was required to observe maximal kainate-induced currents in GluR6-expressing cells. Kainate $(10 \mu \mathrm{M})$ responses were inhibited only $16 \pm 1 \%(n=$ $6)$ and $28 \pm 1 \%(n=8)$ by 50 and $100 \mathrm{~mm}$ ethanol, respectively. However, a lower concentration $(0.2 \mu \mathrm{M})$ of kainate resulted in greater ethanol inhibition (Fig. 1).

To examine more fully the potential subunit differences in ethanol sensitivity between GluR3 and GluR6 receptors, we measured kainate and ethanol concentration-response curves for these two homomeric receptors (Fig. $2 A-C$ ). Ethanol (100 mM) inhibited the maximal kainate-induced response in oocytes expressing GluR3 and GluR6 receptors without altering the $\mathrm{EC}_{50}$ value for kainate (Fig. 2A,B). As observed in Figure 1 in the presence of two concentrations of kainate, the inset graphs in Figure 2, $A$ and $B$, show that the percentage ethanol inhibition decreases as the kainate concentration increases for GluR6 but not GluR3 receptors. Next, the ethanol sensitivities of GluR3 and GluR6 receptors were directly compared using 10-600 mM ethanol in the presence of maximum kainate concentrations (Fig. $2 C$ ). Ethanol produced a concentration-dependent inhibition of kainate responses for both receptor subtypes. The $\mathrm{IC}_{50}$ values for ethanol inhibition of maximum kainate responses were significantly different for these receptors, with GluR3 channels being approximately twofold more sensitive to ethanol than GluR6 channels.

\section{Role of extracellular $\mathrm{Ca}^{2+}$ in ethanol inhibition of kainate responses}

The differential ethanol sensitivity of GluR3 and GluR6 receptors shown above suggested that $\mathrm{Ca}^{2+}$-permeable GluR channels might be more sensitive to ethanol inhibition compared to low or non- $\mathrm{Ca}^{2+}$-permeable channels. Therefore, we expressed $\mathrm{Ca}^{2+-}$ permeable GluR subunits and compared the ethanol inhibition of kainate currents in normal- and high- $\mathrm{Ca}^{2+}$ buffers following the protocol of Hollmann et al. (1991). In agreement with Hollmann et al. (1991), no kainate responses were observed in $\mathrm{Na}^{+}$/ $\mathrm{K}^{+}$-free Ringer containing a normal $\mathrm{Ca}^{2+}$ concentration (data not shown), suggesting that the kainate current obtained in normal Ringer is primarily due to $\mathrm{Na}^{+}$influx. We observed large kainate-stimulated currents in $\mathrm{Ca}^{2+}$ Ringer that contained $10 \mathrm{~mm}$ $\mathrm{Ca}^{2+}$ as the only permeant ion; in fact, peak responses in $\mathrm{Ca}^{2+}$ Ringer were greater than those recorded in normal Ringer and exhibited greater desensitization, presumably due to activation of $\mathrm{Ca}^{2+}$-dependent $\mathrm{Cl}$ currents in the oocyte (Fig. 3A). The responses also decreased with repeated applications that is characteristic of $\mathrm{Ca}^{21}$-dependent $\mathrm{Cl}$ currents (Singer et al., 1990). Interestingly, ethanol inhibition of kainate responses was greatly enhanced in $\mathrm{Ca}^{2+}$ Ringer compared to normal Ringer (Fig. 3A). The greater ethanol inhibition cannot be attributed to changes in 
A.
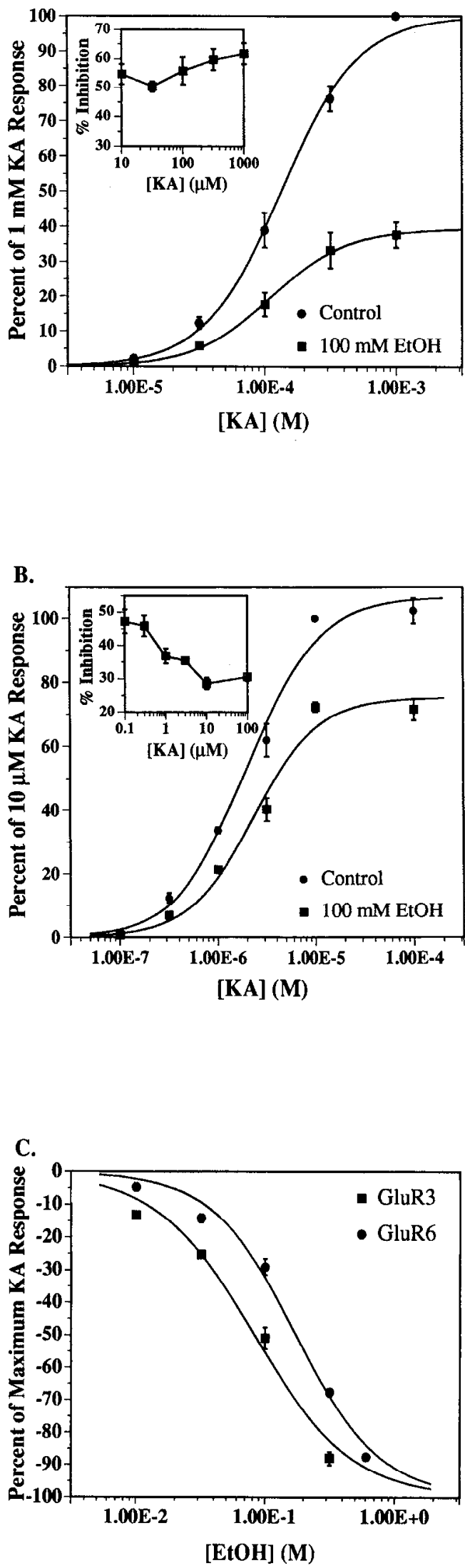

Figure 2. Ethanol produces greater inthibition of GluR3 compared to GluR6 kainate responses. $A$, Kainate $(K A ; 10-1000 \mu \mathrm{M})$ in the absence and presence of $100 \mathrm{~mm}$ ethanol (EtOH) was tested in GluR3-expressing oocytes. The $\mathrm{EC}_{50}$ value for kainate was 130 and $110 \mu \mathrm{M}$ in the the $\mathrm{EC}_{50}$ for kainate since this value does not change in $\mathrm{Ca}^{2+}$ Ringer (Hollmann et al., 1991). Ethanol alone (100 mM) produced current oscillations in $\mathrm{Ca}^{2+}$ but not normal Ringer in 3 of 11 cells, and these oscillations were abolished after injection of EGTA (see Fig. $3 A, B$ ). In 2 of 11 cells, ethanol alone (100 mM) produced oscillations in the absence of EGTA in both normal and $\mathrm{Ca}^{2+}$ Ringer. This is likely due to release of intracellular $\mathrm{Ca}^{2+}$ and activation of $\mathrm{Ca}^{2+}$-stimulated $\mathrm{Cl}^{-}$currents in some sensitive oocytes (Wafford et al., 1989).

To prevent activation of $\mathrm{Ca}^{2+}$-stimulated $\mathrm{Cl}^{-}$currents in $\mathrm{Ca}^{2+}$ Ringer, $100 \mu \mathrm{M}$ FGTA was injected before recording. The ability of EGTA to block $\mathrm{Ca}^{2+}$-stimulated $\mathrm{Cl}^{-}$currents was verified in oocytes expressing the $5 \mathrm{HT}_{1 \mathrm{C}}$ metabotropic receptor clone in which 5-HT was used to activate $5 \mathrm{HT}_{1 \mathrm{C}}$ receptor-G-protein coupled production of $\mathrm{IP}_{3}$ that then activates $\mathrm{Ca}^{2+}$-stimulated $\mathrm{Cl}^{-}$ currents endogenous to the oocyte. Large (up to $1 \mu \mathrm{A}$ ) $\mathrm{Ca}^{2}$ stimulated $\mathrm{Cl}^{-}$currents produced by 5-HT-induced activation of $5 \mathrm{HT}_{1 \mathrm{C}}$ receptors were inhibited by $86 \pm 5.0 \%$ and $100 \%$ by 100 and $200 \mu \mathrm{M}$ EGTA, respectively $(n=3)$. EGTA also blocked the transient, rapidly desensitizing component of the kainateinduced $\mathrm{Ca}^{2+}$ response and resulted in a lower peak kainate response in $\mathrm{Ca}^{2+}$ Ringer compared to normal Ringer and also improved the consistency of kainate responses with repeated applications (Fig. 3B). As noted above, EGTA did not block the slow receptor descnsitization that is also observed in normal buffer. The greater ethanol inhibition of kainate-stimulated $\mathrm{Ca}^{2+}$ current remained after 100-200 $\mu$ M EGTA injection (Figs. $3 B$, 4 ), and thus was not likely due to an ethanol interaction with $\mathrm{Ca}^{2+}$-stimulated $\mathrm{Cl}^{-}$currents since EGTA is an effective blocker of $\mathrm{Ca}^{2+}$-stimulated $\mathrm{Cl}^{-}$currents in the oocyte. However, to test the possibility that ethanol might have some direct effect on the $\mathrm{Ca}^{2+}$-stimulated $\mathrm{Cl}^{-}$current, we examined $\mathrm{IP}_{3}$-induced $\mathrm{Ca}^{2+}$ stimulated $\mathrm{Cl}^{-}$currents in the absence and presence of $100 \mathrm{~mm}$ ethanol and found that ethanol (applied before and during the $\mathrm{IP}_{3}$-mediated response) had no effect on these currents $(-55.4$ $\pm 11.9 \mathrm{nA}$ and $-51.9 \pm 10.9 \mathrm{nA}$ in the absence and presence of ethanol, respectively; $n=14$ ). In addition to $\mathrm{Ca}^{2+}$-permeable GluRs (GluR1, GluR3, and GluR1+3), the greater ethanol inhibition of $\mathrm{Ca}^{2+}$ compared to $\mathrm{Na}^{+}$currents was also observed in oocytes expressing rat whole-brain mRNA in the presence of EGT (Fig. 4A). EGTA did not affect the ethanol inhibition in normal buffer when compared within the same (data not shown) or between different oocytes (Fig. 5B).

To compare ethanol sensitivities of $\mathrm{Na}^{+}$- versus $\mathrm{Ca}^{2+}$-medi-

$\leftarrow$

absence and presence of ethanol, respectively. Values represent mean ( $\pm \mathrm{SEM})$ percentage of $1 \mathrm{~mm}$ kainate response $(n=4-6)$; values in the inset graph have been expressed as mean ( \pm SEM) percentage inhibition produced by ethanol as a function of kainate concentration. Error bars not visible are smaller than symbol. $B$, Kainate $(0.1-100 \mu \mathrm{M})$ in the absence and presence of $100 \mathrm{~mm}$ ethanol was tested in GluR6expressing oocytes. The $\mathrm{EC}_{50}$ value for kainate was 2.0 and $2.3 \mu \mathrm{M}$ in the absence and presence of ethanol, respectively. Values represent mean $( \pm$ SEM) percentage of $10 \mu \mathrm{M}$ kainate response $(n=4-12)$; values in the inset graph have been expressed as mean ( \pm SEM) percentage inhibition produced by ethanol as a function of kainate concentration. Error bars not visible are smaller than symbol. $C$, Ethanol (10$600 \mathrm{~mm}$ ) was tested in the presence of maximum kainate concentrations for GluR3 and GluR6 receptors. The $\mathrm{IC}_{50}$ value for ethanol was 82 and $170 \mathrm{~mm}$ for GluR3 and GluR6 receptors, respectively $(p<0.01)$. Values represent mean ( \pm SEM) percentage of $10 \mu \mathrm{M}$ (GluR6) or $400 \mu \mathrm{M}$ (GluR3) kainate responses $(n=4-7)$. Error bars not visible are smaller than symbol. 

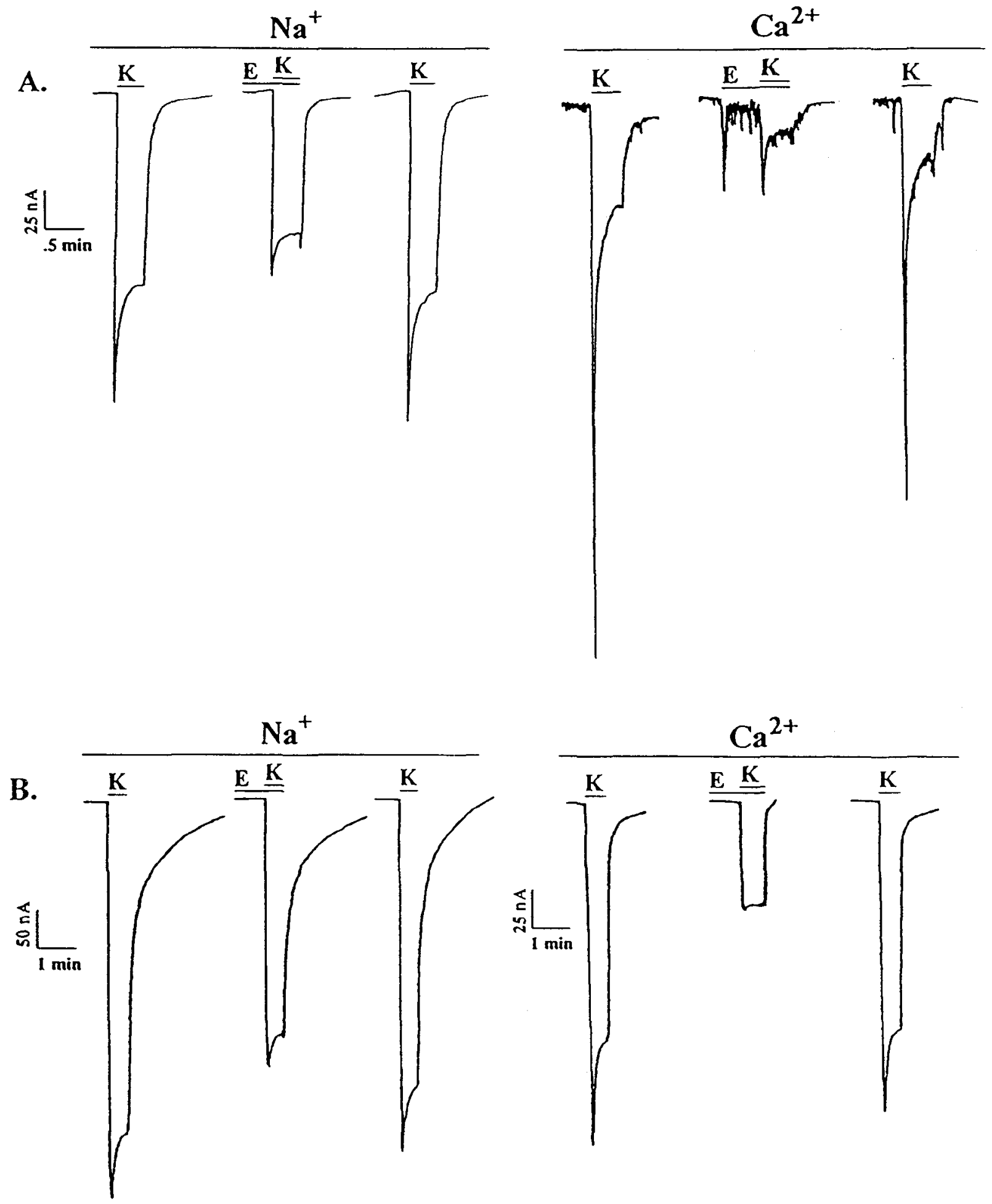

Figure 3. EGTA did not prevent greater ethanol inhibition of kainate responses in high-Ca $\mathrm{Ca}^{2+}$ buffer but blocked $\mathrm{Ca}^{2+}$-stimulated $\mathrm{Cl}^{-}$currents in high- $\mathrm{Ca}^{2+}$ buffer. $A$, Current responses to $400 \mu \mathrm{M}$ kainate $(K)$ were recorded in the absence and presence of $100 \mathrm{mM}$ ethanol $(E)$ in normal $\left(\mathrm{Na}^{+}\right)$or $\mathrm{Ca}^{2+}$ Ringer $\left(\mathrm{Ca}^{2+}\right)$ in a GluR $1+3$-expressing oocyte. Currents in normal and $\mathrm{Ca}^{2+}$ Ringer represent $\mathrm{Na}^{+}$- and Ca ${ }^{2+}$-mediated currents, respectively; the oscillations induced by ethanol alone in $\mathrm{Ca}^{2+}$ Ringer were only observed in some sensitive oocytes (see Results). Horizontal bars indicate time of drug application. In $B$, conditions were identical to those in $A$, except that EGTA (100 $\mu M$ final concentration) was injected before recording.

ated kainate currents, the effects of $10-316 \mathrm{~mm}$ ethanol were tested in normal and $\mathrm{Ca}^{2+}$ Ringer using GluR3-expressing oocytes (Fig. $4 B$ ). EGTA $(200 \mu \mathrm{M})$ was injected before recording to block activation of $\mathrm{Ca}^{2+}$-stimulated $\mathrm{Cl}^{-}$currents in $\mathrm{Ca}^{2+}$ Ring- er. In the presence of $200 \mu \mathrm{M}$ EGTA, an ethanol concentration of $10 \mathrm{mM}$ produced significant inhibition in $\mathrm{Ca}^{2+}$ Ringer whereas a concentration of approximately $30 \mathrm{mM}$ was required to produce a threshold effect in normal Ringer (Fig. 4B). 

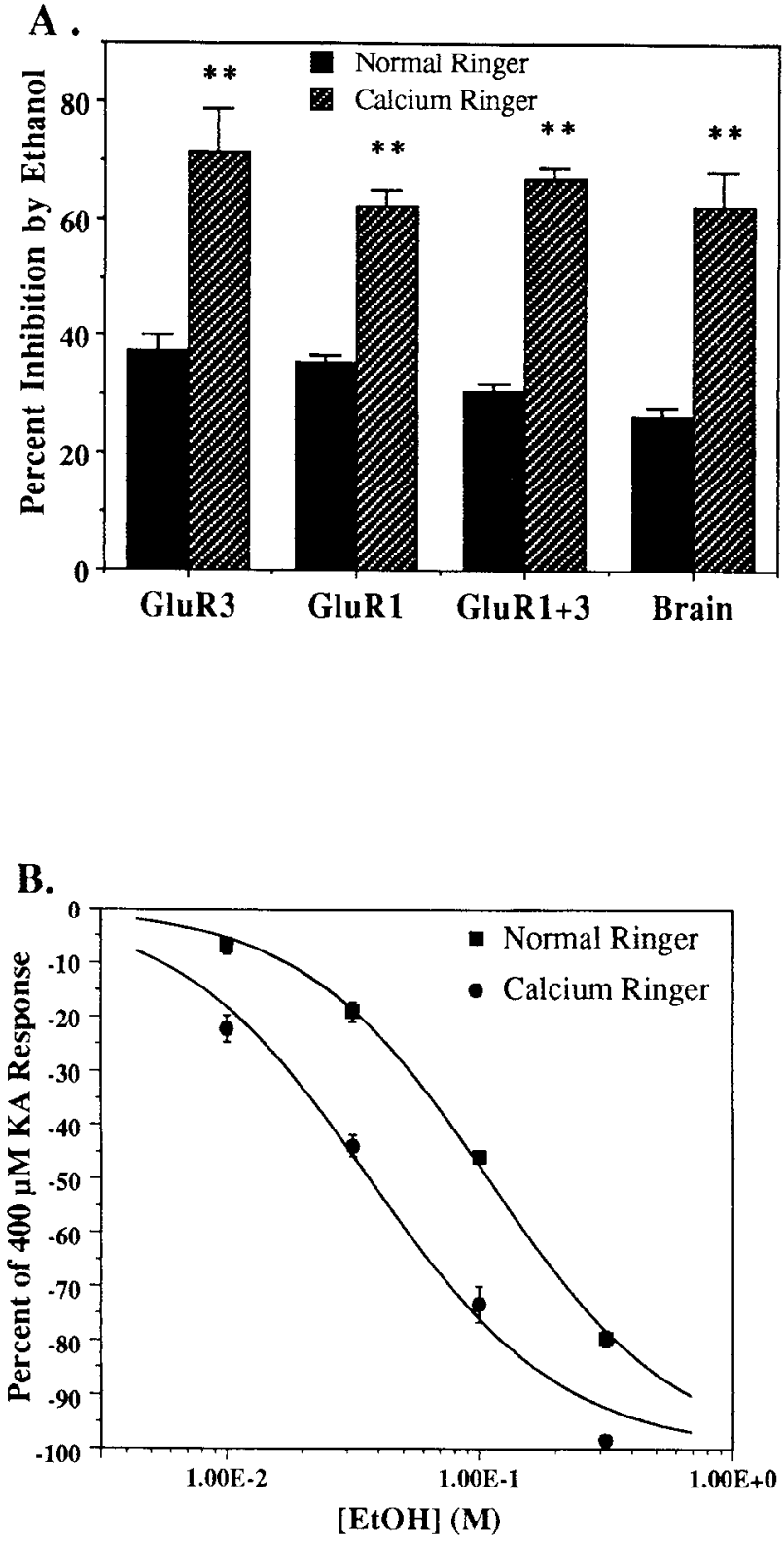

Figure 4. Ethanol inhibition of kainate responses is greater with high$\mathrm{Ca}^{2}$ - bufter than with normal buffer. $A$, following EGI'A (100 $\left.\mu \mathrm{M}\right)$ injection. ethanol $(100 \mathrm{~mm})$ inhibition of kainate $(400 \mu \mathrm{M})$ responses was compared in normal and $\mathrm{Ca}^{2+}$ Ringer for oocytes expressing either GluR1, GluR3, GluR1+3 cRNA, or rat whole-brain mRNA. Values represent the mean (+SEM) percentage inhibition of kainate currents produced hy ethanol $(n=3-5)$. **, $p<0.01$ compared to normal Ringer. $B$, After EGTA $(200 \mu \mathrm{M})$ injection, ethanol (10-316 mM) inhibition of $400 \mu \mathrm{M}$ kainate responses was compared in normal and $\mathrm{Ca}^{2+}$ Ringer in GluR3 expressing oocytes. The $\mathrm{IC}_{511}$ value for ethanol was 108 and $37 \mathrm{~mm}$ in normal Ringer and $\mathrm{Ca}^{2}$ Ringer, respectively $(p<$ $0.001)$. Values represent the mean ( \pm SEM) percentage of kainate currents produced by ethanol $(n=6-14)$. Error bars not visible are smaller than symbol.

Role of extracellular cation and intracellular $\mathrm{Ca}^{2}$ in ethanol inhibition of kainate responses

To determine if the enhanced ethanol inhibition in $\mathrm{Ca}^{2}+$ Ringer was due to greater ethanol inhibition of $\mathrm{Ca}^{2+}$ compared to $\mathrm{Na}^{+}$ flux or to a secondary $\mathrm{Ca}^{2}$-dependent intracellular process, $\mathrm{Ba}^{2}$ was substituted for $\mathrm{Ca}^{2}$. These studies were performed in the presence of EGTA to block activation of $\mathrm{Cl}$ currents; although
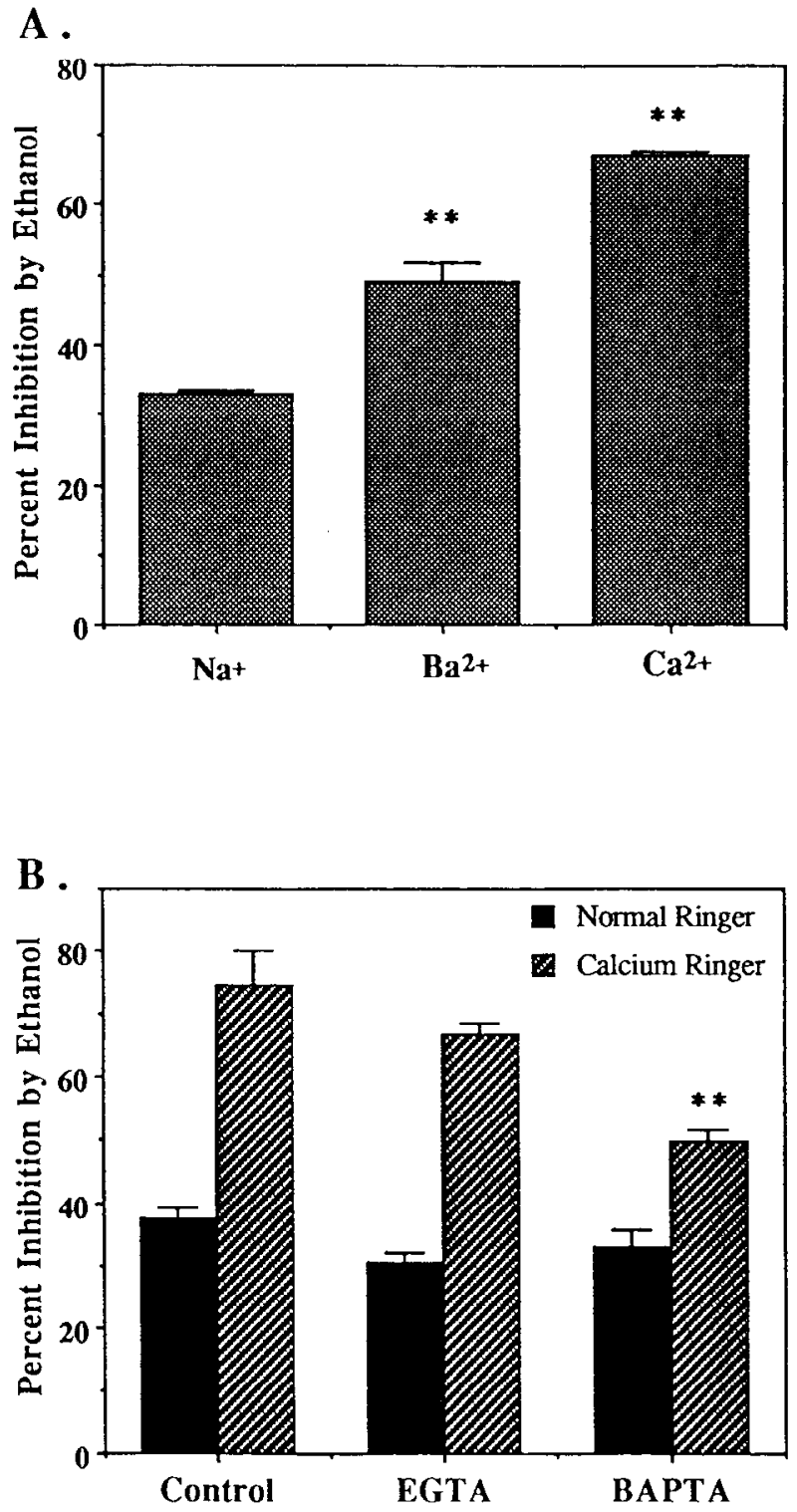

Figure 5. A, Ethanol inhibition depends on the permeant cation. After injection of $100 \mu \mathrm{M}$ EGTA, ethanol (100 mM) inhibition of kainate $(40)$ $\mu \mathrm{M})$ responses was compared in normal Ringer $\left(\mathrm{Na}^{+}\right)$. Ba ${ }^{2}$. Ringer $\left(B a^{2+}\right)$ containing $60 \mathrm{~mm} \mathrm{Ba} a^{2}$ as the only permeant cation, and $\mathrm{Ca}^{2+}$ Ringer $\left(\mathrm{Ca}^{2}\right)$ containing $10 \mathrm{~mm} \mathrm{Ca}{ }^{2-}$ as the only permeant cation. Oocytes expressing cither GluR3 or GluR $1+3$ receptors were tested. Values represent the mean $(+S E M)$ percentage inhibition of kainate currents produced by ethanol $(n=5-6)$. **, $p<0.01$ compared to normal Ringer. $B$, BAPTA reduces ethanol inhibition in high- $\mathrm{Ca}^{2-}$ Ringcr. Ethanol $(100 \mathrm{~mm})$ inhibition of kainate $(400 \mu \mathrm{M})$ responses was compared in normal- and high-Ca $\mathrm{Ca}^{2-}$ Ringer in the absence of chelator (Control), and in the presence of $100 \mu \mathrm{M}$ EGTA or $500 \mu \mathrm{M}$ BAPTA in GluR 1+3-injected oocytes. Values represent the mean (+SEM) percentage inhibition of kainate currents produced by ethanol $(n=5-9)$. $* *, p<0.01$ compared to control and HGTA.

$\mathrm{Ba}^{2-}$ is a poor activator of these currents, EGTA was injected so that all currents $\left(\mathrm{Na}, \mathrm{Ba}^{2}, \mathrm{Ca}^{2} \cdot\right)$ were measured under the same conditions. The cthanol inhibition of $\mathrm{Ba}^{2--}$-induced kainate currents was intermediate between that of $\mathrm{Na}^{-}$and $\mathrm{Ca}^{2+}$-induced currents (Fig. 5A). BAPTA is a faster and more efficient $\mathrm{Ca}^{2+}$ chelator than EGTA, and we next compared the ethanol inhibition of kainate responses in the absence and presence of EGTA or BAPTA in oocytes expressing GluRI +3 receptors. 
A .

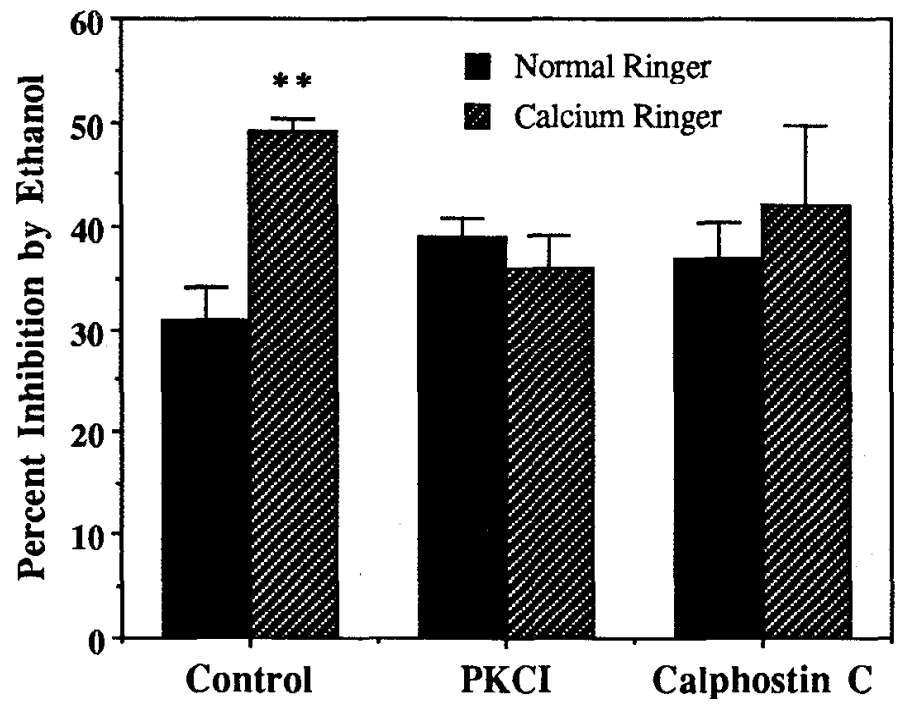

Figure 6. Inhibition of PKC prevents enhanced ethanol inhibition in $\mathrm{Ca}^{2+}$ Ringer. A, Ethanol (100 mM) inhibition of kainate $(400 \mu \mathrm{M})$ responses in normal- and high- $\mathrm{Ca}^{2+}$ Ringer in GluR3or GluR1+3-expressing oocytes after injection of $500 \mu \mathrm{M}$ BAPTA alone (Control), $500 \mu \mathrm{M}$ BAPTA + $300 \mathrm{ng}$ PKCI $(P K C D)$, or $1 \mu \mathrm{M}$ calphostin $\mathrm{C} \pm$ $500 \mu \mathrm{M}$ BAPTA (Calphostin $C$ ). Values represent the mean $(+$ SEM) percentage inhibition of kainate currents produced by ethanol $(n=3-4)$.**, $p$ $<0.01$ compared to normal Ringer. $B$, Ethanol (100 mM) inhibition of $400 \mu \mathrm{M}$ kainate-induced currents in normal$\left(\mathrm{Na}^{+}\right)$and high- $\mathrm{Ca}^{2+}\left(\mathrm{Ca}^{2+}\right)$ Ringer recorded after injection of calphostin $\mathrm{C}$ alone.

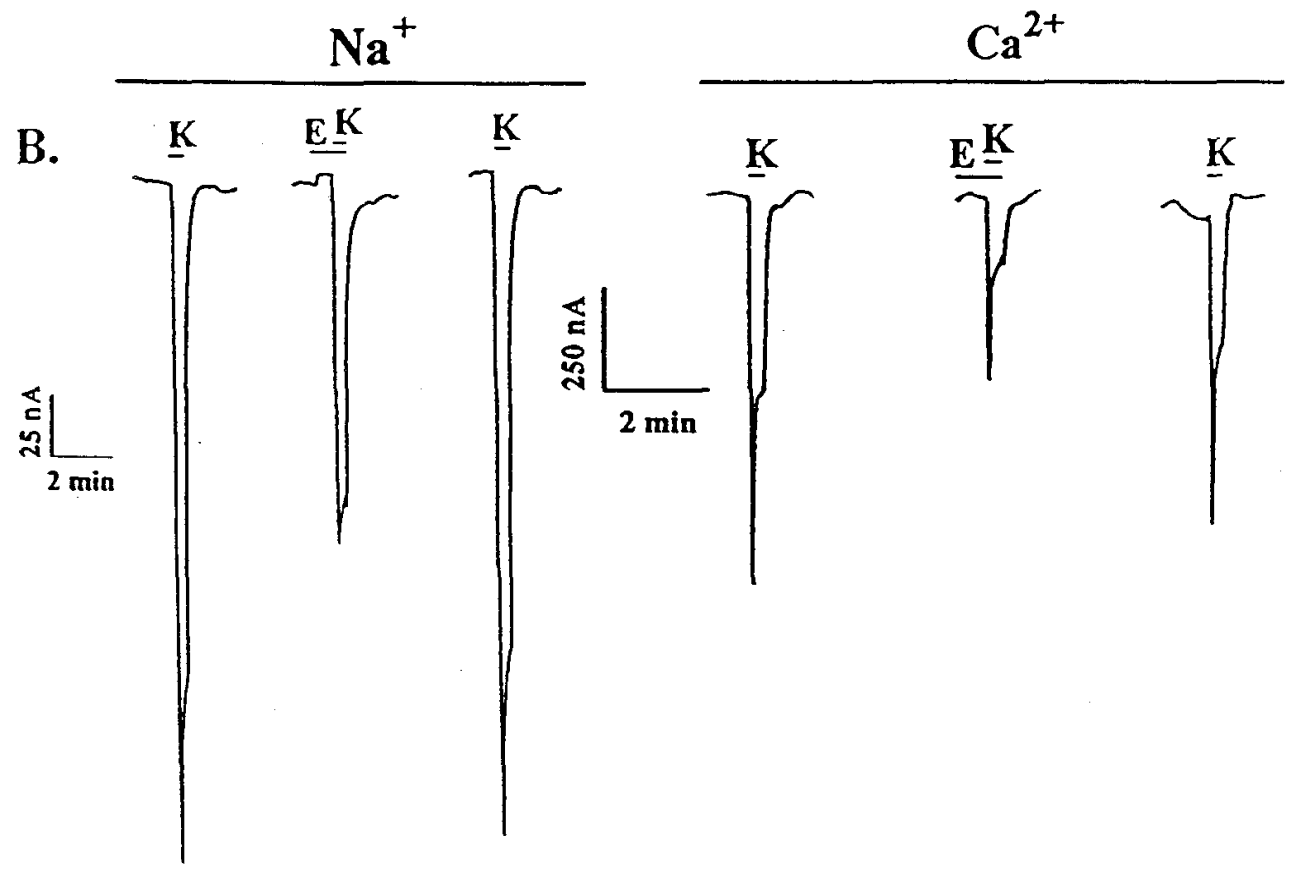

Ethanol inhibition of $\mathrm{Ca}^{2+}$ currents was greater than the inhibition of $\mathrm{Na}^{+}$currents both in the absence and presence of EGTA, whereas in the presence of BAPTA, ethanol inhibition in $\mathrm{Ca}^{2+}$ Ringer was reduced, although still greater compared to normal buffer (Fig. 5B). BAPTA did not affect the ethanol inhibition of kainate responses in normal buffer when compared within the same oocyte (e.g., $41 \pm 3.0 \%$ and $40 \pm 1.3 \%$ before and after $500 \mu \mathrm{M}$ BAPTA, respectively; $n=3$ ). Thus, ethanol inhibition was not significantly affected by either chelator in normal Ringer; however, in $\mathrm{Ca}^{2+}$ Ringer the enhanced ethanol inhibition was significantly less in the presence of BAPTA.
Role of PKC in ethanol inhibition of kainate responses

The above results suggested that the greater ethanol sensitivity in $\mathrm{Ca}^{2+}$ Ringer may be due to an intracellular $\mathrm{Ca}^{2+}$-dependent mechanism. Based on the PKC consensus sites that are present in GluRs (Keinänen et al., 1990) and our studies demonstrating that the PKC activator PMA inhibits kainate responses in $\mathrm{Ca}^{2+}$ permeable GluR receptors via a PKC-dependent mechanism (Dildy-Mayfield and Harris, 1994), a potential role for $\mathrm{Ca}^{2+}$ mediated activation of $\mathrm{PKC}$ was investigated. Injection of the specific PKC inhibitor peptide (PKCI), or the PKC inhibitor calphostin $\mathrm{C}$, prevented the enhanced ethanol inhibition of kainate 
responses in $\mathrm{Ca}^{2+}$ Ringer (Fig. 6A). For experiments with PKCI, BAPTA was also present to block $\mathrm{Ca}^{2+}$-stimulated $\mathrm{Cl}^{-}$currents For studies with calphostin $\mathrm{C}$, some oocytes were not injected with BAPTA so that the effect of PKC inhibition could be evaluated alone, that is, in the absence of BAPTA, which itself significantly reduces the ethanol inhibition in $\mathrm{Ca}^{2+}$ Ringer. As shown in Figure $6 \mathrm{~B}$, calphostin $\mathrm{C}$ alone prevented the greater ethanol inhibition in $\mathrm{Ca}^{2+}$ compared to normal Ringer. Inhibition of PKC using either PKCI or calphostin C did not, however, affect the ethanol inhibition of kainate with normal buffer. For example, the ethanol inhibition was $30 \pm 3.5 \%$ and $32 \pm 1.2 \%$ before and after PKCI, respectively, $(n=3)$; before and after calphostin $C$, the ethanol inhibition was $44 \pm 4.5 \%$ and $45 \pm$ $3.5 \%$, respectively $(n=3)$.

To evaluate further the role of PKC in ethanol inhibition of kainate responses, we compared cthanol sensitivity before and after PMA exposure in $\mathrm{Ca}^{2+}$-permeable GluR $1+3$ receptors. PMA (50 nM) inhibited kainate responses in these oocytes by $53 \pm 11 \%(n=7)$ as reported previously (Dildy-Mayfield and Harris, 1994). The effect of ethanol was measured before and 30-40 min after PMA when kainate responses were maximally inhibited. The percentage ethanol inhibition was $31 \pm 1.8 \%$ and $40 \pm 2.1 \%$ before and after PMA, respectively $(n=7)$.

\section{Discussion}

This report demonstrates that multiple subtypes of AMPA/kainate channels are ethanol sensitive. Although the ethanol inhibition varied depending on the GluR subunits and the kainate concentration, all subunits tested were inhibited by ethanol, indicating that no single subunit studied was required for ethanol sensitivity.

Our results suggest that the greater ethanol inhibition of low concentrations of kainate first observed in oocytes expressing brain mRNA (Dildy-Mayfield and Harris, 1992) may be explained by ethanol's action on subtypes of glutamate receptors. Compared to GluR3, GluR6 kainate channels were approximately twofold less sensitive to inhibition by ethanol in the presence of maximum kainate concentrations. For both receptors, ethanol inhibited the maximal kainate response without altering the $\mathrm{EC}_{50}$, indicating a noncompetitive type of inhibition. The GluR3 and GluR6 receptors represent different families of glutamate receptors, and we found that the kainate sensitivity of the GluR6 (kainate-selective) receptor expressed in oocytes was greater than for other GluR subunits. Kainate $\mathrm{EC}_{50}$ values of 1 and $1.6 \mu \mathrm{M}$ for GluR6 receptors (Egebjerg et al., 1991; Sakimura et al., 1992) and $130 \mu \mathrm{M}$ for GluR3 receptors (Nakanishi et al., 1990) have been reported in oocytes, and these values agree with our present results.

The only studies of the effects of ethanol on specific AMPA/ kainate receptor subunits (present data and Lovinger, 1993) indicate that several subtypes of GluRs are clearly ethanol sensitive. The ethanol inhibition of kainate currents in HEK 293 cells transfected with GluR 1, GluR4, GluRl +4, or GluR2 +4 receptors (Lovinger, 1993) agrees with our results in oocytes, although we found differential cthanol sensitivity that depended on the kainate concentration for some of the GluRs. We also found differences in ethanol sensitivity between GluR3 and GluR6 subunits that are from two different families of GluRs, whereas Lovinger (1993) only compared ethanol actions among subunits from a single family of GluRs. Recombinant GluRs expressed in oocytes and HEK 293 cells are much more sensitive to ethanol than AMPA/kainate receptors studied in brain
(Lovinger et al., 1989). In fact, the ethanol sensitivity of recomhinant GluRs is similar to that reported for recombinant NMDA receptors (Koltchine et al., 1993; Masood et al., 1994). We (Dildy-Mayfield and Harris, 1992) and Teichberg et al. (1984) reported similar ethanol inhibition of NMDA and non-NMDA responses, although other studies show that NMDA responses are more sensitive to inhibition by ethanol than non-NMDA responses (Hoffman et al., 1989; Lovinger et al., 1989). If ethanol sensitive and resistant AMPA/kainate receptors are expressed in vivo, then effects of ethanol on brain receptors would represent an average of all receptors present that may explain some of the discrepancies in the literature. The effects of ethanol on the GluR2 subunit alone have not been assessed due to its poor expression, but our results indicate that coexpression of this subunit with GluR3 decreases the ethanol inhibition of maximum kainate responses in comparison to GluR3 alone. Other GluR receptors may exist that are not inhibited by ethanol; in addition, coexpression of existing subunits (e.g., KA-1 and KA-2) with GluR5 or GluR6 (Herb et al., 1992; Sakimura et al., 1992) may reveal constructs with different ethanol sensitivities. Thus, the possibility of ethanol-resistant AMPA/KA receptors cannot be excluded. Although we do not have direct evidence for an ethanol insensitive AMPA/KA receptor, we have presently shown that differences in the magnitude of ethanol sensitivity do exist among some of the subunits.

One goal of this study was to determine if the cation permeability of GluR channels influenced the sensitivity to ethanol. For $\mathrm{Ca}^{2+}$-permeable GluRs, we showed that the percentage inhibition of kainate responses by ethanol doubles when $\mathrm{Ca}^{2+}$ rather than $\mathrm{Na}^{+}$is the permeant cation. This was also true for GluRs expressed from brain mRNA, suggesting that $\mathrm{Ca}^{2+}$-permeable kainate-sensitive channels may be expressed in brain and that the enhanced ethanol sensitivity in $\mathrm{Ca}^{2+}$ Ringer is not limited to cloned GluRs. Interestingly, ethanol inhibition of NMDA-mediated responses in NMDAR 1-expressing oocytes is greater when $\mathrm{Ca}^{2+}$ rather than $\mathrm{Ba}^{2+}$ is the permeant cation, although the mechanism for this difference was not studied (Koltchine et al., 1993). The activity of GluR6 channels is sensitive to extracellular variations in the concentration of $\mathrm{Ca}^{2+}$ (Egebjerg et al., 1991), but this type of $\mathrm{Ca}^{2+}$-dependent reduction in current is not observed for the GluR 1-4 subunits (Hollmann et al., 1991). To determine if the difference in ethanol sensitivity was due to greater inhibition of $\mathrm{Ca}^{2+}$ compared to $\mathrm{Na}^{+}$currents or to a secondary $\mathrm{Ca}^{2+}$-mediated mechanism, we injected EGTA. Although EGTA is an effective blocker of $\mathrm{Ca}^{2+}$-stimulated $\mathrm{Cl}^{-}$currents in oocytes as shown by our results from the $5 \mathrm{HT}_{1 \mathrm{C}}$. receptor, it did not prevent the greater ethanol inhibition observed in $\mathrm{Ca}^{2+}$ Ringer. This indicated that the enhanced ethanol inhibition was not due to ethanol inhibition of $\mathrm{Ca}^{2+}$-stimulated $\mathrm{Cl}^{-}$currents that agrees with our previous work showing that ethanol does not affect these currents (Sanna et al., 1994). We studied this further by examining the effects of a continuous ethanol exposure on $\mathrm{IP}_{3}$-induced $\mathrm{Ca}^{2+}$-stimulated $\mathrm{Cl}^{-}$currents in the oocyte and found that even with longer exposure times ethanol does not directly affect these currents. Other evidence against a direct effect of ethanol on the $\mathrm{Ca}^{2+}$-stimulated $\mathrm{Cl}^{-}$current in ooyctes was reported by Ilyin and Parker (1992), who showed that even a high ethanol concentration $(320 \mathrm{~mm})$ produced only a $15 \%$ reduction in this current. Further characterization showed that the ethanol inhibition depended on the permeant cation $\left(\mathrm{Ca}^{2+}>\right.$ $\mathrm{Ba}^{2+}>\mathrm{Na}^{+}$). Because $\mathrm{Ba}^{2+}$ can activate some $\mathrm{Ca}^{2+}$-dependent processes (Knight et al., 1988; Sekiguchi et al., 1988; Przywara 
et al., 1993), the enhanced ethanol inhibition of $\mathrm{Ca}^{2+} / \mathrm{Ba}^{2+}$ flux may be due to activation of a secondary $\mathrm{Ca}^{2+}$-dependent mechanism. Injection of EGTA could reduce the ethanol inhibition of $\mathrm{Ca}^{2+}$ responses if this involved an intracellular $\mathrm{Ca}^{2+}$-dependent mechanism; however, EGTA is a slow $\mathrm{Ca}^{2+}$ chelator and was only present in micromolar concentrations. BAPTA is a faster and more efficient $\mathrm{Ca}^{2+}$ chelator, and we injected it in higher concentrations and found that it was able to reduce the ethanol inhibition of kainate responses in high $\mathrm{Ca}^{2+}$ buffer. BAPTA did not affect ethanol inhibition in normal buffer, indicating that the reduced ethanol inhibition in high- $\mathrm{Ca}^{2+}$ buffer was not due to an overall decreased ethanol sensitivity in the presence of BAPTA. The ethanol inhibition was still greater compared to that in normal buffer perhaps because of the inability of BAPTA to effectively chelate $\mathrm{Ca}^{2+}$ under high-Ca ${ }^{2+}$ conditions. Even strong buffering with very high concentrations of BAPTA may be overcome when the $\mathrm{Ca}^{2+}$ influx is large (Legendre et al., 1993).

The large inhibition of $\mathrm{Ca}^{2+}$ flux by ethanol was decreased in the presence of BAPTA, indicating an intracellular $\mathrm{Ca}^{2+}$-dependent mechanism and suggesting that greater ethanol inhibition of $\mathrm{Ca}^{2+}$ compared to $\mathrm{Na}^{+}$conductance was not a likely mechanism. Of the many $\mathrm{Ca}^{2+}$-mediated processes that might be responsible for the enhanced ethanol sensitivity, we focused on the role of PKC based on the existence of PKC consensus sites among the GluRs (Keinänen et al., 1990) and PKC-dependent receptor phosphorylation (McGlade-McCulloh et al., 1993) together with our work showing that activation of PKC inhibited kainate-induced currents in oocytes expressing different GluR subunits (Dildy-Mayfield and Harris, 1994). However, there are reports that failed to show modulation of AMPA/kainate receptors by PKC (Sigel and Baur, 1988; Chen and Huang, 1992; Kelso et al., 1992), indicating that PKC modulation may not be a common mechanism for all of the GluRs or that the conditions required for PKC-dependent phosphorylation may be slightly different for different GluRs. We found that the PKC inhibitor peptide or the PKC inhibitor calphostin $\mathrm{C}$ prevented the enhanced ethanol inhibition in high- $\mathrm{Ca}^{2+}$ buffer but had no effect in normal buffer. Thus, inhibition of PKC blocked the greater ethanol inhibition of kainate responses in high-Ca ${ }^{2+}$ buffer, supporting a role for $\mathrm{Ca}^{2+}$-mediated activation of PKC. Although the GluRs have consensus sites for $\mathrm{Ca}^{2+} /$ calmodulin-dependent protein kinase as well (Keinänen et al., 1990), functional studies have shown that activation of this kinase enhances rather than inhibits channel function (McGlade-McCulloh et al., 1993). Furthermore, our results indicating that $\mathrm{Ba}^{2+}$ can partially substitute for $\mathrm{Ca}^{2+}$ in mediating enhanced sensitivity to ethanol would argue against a role for $\mathrm{Ca}^{2+} /$ calmodulin-dependent protein kinase because $\mathrm{Ba}^{2+}$ is a poor activator of calmodulin-dependent processes (Chao et al., 1984). However, $\mathrm{Ba}^{2+}$ has been shown to activate PKC (Knight et al., 1988; Sekiguchi et al., 1988).

Potential PKC-dependent mechanisms for the enhanced ethanol inhibition of $\mathrm{Ca}^{2+}$ currents include the following: (1) $\mathrm{Ca}^{2+}$ activates $\mathrm{PKC}$, increasing phosphorylation of the receptor or associated protein(s), which in turn increases the ethanol sensitivity of the channel; or (2) $\mathrm{Ca}^{2+}$ and ethanol synergistically activate $\mathrm{PKC}$, markedly increasing phosphorylation of the receptor, which further inhibits receptor function. The first mechanism proposes that ethanol acts directly on the receptor/channel complex under normal and elevated $\mathrm{Ca}^{2+}$ conditions, and this action is increased by $\mathrm{PKC}$-mediated phosphorylation of the receptor. The second mechanism proposes that ethanol has two actions under high- $\mathrm{Ca}^{2+}$ conditions in that it acts directly on the recep- tor/channel complex to produce approximately $40 \%$ inhibition (as $100 \mathrm{mM}$ ethanol does under normal conditions) and it also increases PKC-dependent phosphorylation that then further inhibits channel function resulting in greater than $70 \%$ inhibition. To discern between these mechanisms, we compared the ethanol sensitivity before and after PMA and found that ethanol inhibition increased only slightly following activation of PKC, indicating that the first mechanism cannot explain the enhanced ethanol sensitivity in high- $\mathrm{Ca}^{2+}$ buffer. The concentration of PMA used was maximally effective, and thus would be expected to produce at least as great an activation of PKC as elevated $\mathrm{Ca}^{2+}$. However, the inhibition by ethanol before and after PMA differed by only $9 \%$, whereas we would have expected the difference to be at least $30 \%$ if phosphorylation of the receptor alone (without an effect on receptor function) was responsible for increased ethanol sensitivity. Thus, a plausible mechanism for the enhanced ethanol inhibition is that elevated $\mathrm{Ca}^{2+}$ allows ethanol activation of $\mathrm{PKC}$ by either direct or indirect actions. Evidence for direct effects of ethanol on PKC activity is controversial, ranging from weak inhibition (Slater et al., 1993) or no effect (Machu et al., 1991) on the purified enzyme, to stimulation of cellular PKC activity (Skwish and Shain, 1990; DePetrillo and Liou, 1993). Although PKC activity is dependent on $\mathrm{Ca}^{2+}$, the effects of $\mathrm{Ca}^{2+}$ in the presence of ethanol are not known. Taken together, available data suggest that ethanol inhibits kainate channel function by two distinct mechanisms: (1) direct inhibition of kainate channel function by a PKC-independent action (which operates under normal- and high $\mathrm{Ca}^{2+}$ conditions) and (2) an additional action of ethanol that increases PKC-dependent phosphorylation of the channel (which occurs with elevated $\mathrm{Ca}^{2+}$ conditions) that in turn inhibits kainate action.

Based on the role of $\mathrm{Ca}^{2+}$ in enhancing ethanol inhibition of these receptors, the ethanol sensitivity of individual neurons may increase with elevated intracellular $\mathrm{Ca}^{2+}$. In addition to $\mathrm{Ca}^{2+}$ permeable GluRs, multiple mechanisms regulate intracellular $\mathrm{Ca}^{2+}$ during neuronal stimulation, including voltage-gated $\mathrm{Ca}^{2}$ channels, other $\mathrm{Ca}^{2+}$-permeable ionotropic ligand-gated channels such as NMDA receptors, and $\mathrm{IP}_{3}$ induced $\mathrm{Ca}^{2+}$ release via metabotropic receptor activation. Thus, activation of one or more of the above processes could elevate $\mathrm{Ca}^{2+}$, resulting in enhanced ethanol sensitivity of AMPA/kainate channels.

In summary, we have shown that both homomeric and heteromeric kainate-sensitive channels from two different families of glutamate receptors are inhibited by ethanol, and the ethanol sensitivity can vary depending on subunit composition and kainate concentration. The ethanol inhibition of AMPA/kainate receptors resembles that of recombinant NMDA receptors (Koltchine et al., 1993; Masood et al., 1994), indicating that NMDA receptors are not necessarily preferentially sensitive to ethanol as originally proposed. Our results suggest that ethanol-mediated inhibition of kainate responses expressed in oocytes may involve two mechanisms, one independent of PKC and another mechanism that depends on activation of PKC under conditions of elevated $\mathrm{Ca}^{2+}$. Other studies have shown that the action of ethanol on 5-HT ${ }_{\text {IC }}$ (Sanna et al., 1994), GABA (Wafford and Whiting, 1992), and NMDA (Snell et al., 1994) receptors may also involve PKC-dependent mechanisms, supporting a general role for $\mathrm{PKC}$ activation in modulation of ethanol-sensitive ionotropic and metabotropic responses. 


\section{References}

Bettler B, Boulter J, Hermans-Borgmeyer I, O'Shea-Greenfield A, Deneris ES, Moll C, Borgmeyer U, Hollmann M, Heinemann S (1990) Cloning of a novel glutamate receptor subunit, GluR5: expression in the nervous system during development. Neuron 5:583-595.

Bettler B, Egebjerg J, Sharma G, Pecht G, Hermans-Borgmeyer I, Moll C, Stevens CF, Heinemann S (1992) Cloning of a putative glutamate receptor: a low affinity kainate-binding subunit. Neuron 8:257-265.

Boulter J, Hollmann M, O'Shea-Greenfield A, Hartley M, Deneris E, Maron C, Heinemann S (1990) Molecular cloning and functional expression of glutamate receptor subunit genes. Science 249:10331037.

Chao S-H, Suzuki Y, Zysk JR, Cheung WY (1984) Activation of calmodulin by various metal cations as a function of ionic radius. Mol Pharmacol 26:75-82.

Chen L, Huang LYM (1992) Protein kinase C reduces $\mathrm{Mg}^{2+}$ block of NMDA-receptor channels as a mechanism of modulation. Nature 356:521-523

Colman A (1984) Expression of exogenous DNA in Xenopus oocytes. In: Transcription and translation: a practical approach (Hames BD, Higgins SJ, eds), pp 49-69. Washington, DC: Oxford.

Dawson TL, Nicholas RA, Dingledine R (1990) Homomeric GluR1 excitatory amino acid receptors expressed in Xenopus oocytes. Mol Pharmacol 38:779-784.

DePetrillo PB, Liou CS (1993) Ethanol exposure increases total protein kinase $\mathrm{C}$ activity in human lymphocytes. Alcohol Clin Exp Res 17: 351-354.

Dildy-Mayfield JE, Harris RA (1992) Comparison of ethanol sensitivity of rat brain kainate, DL- $\alpha$-amino-3-hydroxy-5-methyl-4-isoxalone propionic acid and $N$-methyl-D-aspartate receptors expressed in Xenopus oocytes. J Pharmacol Exp Ther 262:487-494.

Dildy-Mayfield JE, Harris RA (1994) Activation of protein kinase C inhibits kainate-induced currents in oocytes expressing glutamate receptor subunits. J Neurochem 62:1639-1642.

Dildy-Mayfield JE, Sikela JM, Harris RA (1991) Evidence for kainate receptor subtypes based on differential ethanol sensitivity of brain and GluR3 receptors expressed in Xenopus oocytes. Soc Neurosci Abstr 17:1167.

Egebjerg J, Heinemann SF (1993) $\mathrm{Ca}^{2+}$ permeability of unedited and edited versions of the kainate selective glutamate receptor GluR6. Proc Natl Acad Sci USA 90:755-759.

Egebjerg J, Bettler B, Hermans-Borgmeyer I, Heinemann S (1991) Cloning of a cDNA for a glutamate receptor subunit activated by kainate but not AMPA. Nature 351:745-748.

Herb A, Burnashev N, Werner P, Sakmann B, Wisden W, Seeburg PH (1992) The KA-2 subunit of excitatory amino acid receptors shows widespread expression in brain and forms ion channels with distantly related subunits. Neuron 8:775-785.

Hoffman PL, Rabe CS, Moses F, Tabakoff B (1989) N-methyl-D-aspartate receptors and ethanol: inhibition of calcium flux and cyclic GMP production. J Neurochem 52:1937-1940.

Hollmann M, Hartley M, Heinemann S (1991) $\mathrm{Ca}^{2+}$ permeability of KA-AMPA-gated glutamate receptor channels depends on subunit composition. Science 252:851-853.

Hume RI, Dingledine R, Heinemann SF (1991) Identification of a site in glutamate receptor subunits that controls calcium permeability. Science 253:1028-1031.

Iino M, Ozawa S, Tsuzuki K (1990) Permeation of calcium through excitatory amino acid receptor channels in cultured rat hippocampal neurones. J Physiol (Lond) 424:151-165.

Ilyin V, Parker I (1992) Effects of alcohols on responses evoked by inositol trisphosphate in Xenopus oocytes. J Physiol (Lond) 448:339354.

Keinänen K, Wisden W, Sommer B, Werner P, Herb A, Verdoorn TA, Sakmann B, Seeburg PH (1990) A family of AMPA-selective glutamate receptors. Science 249:556-560.

Kelso SR, Nelson TE, Leonard JP (1992) Protein kinase C-mediated enhancement of NMDA currents by metabotropic glutamate receptors in Xenopus oocytes. J Physiol (Lond) 449:705-718.

Knight DE, Sugden D, Baker PF (1988) Evidence implicating protein kinase $\mathrm{C}$ in exocytosis from electropermeabilized bovine chromaffin cells. J Membr Biol 104:21-34.

Köhler M, Burnashev N, Sakmann B, Seeburg PH (1993) Determinants of $\mathrm{Ca}^{2+}$ permeability in both TM1 and TM2 of high affinity kainate receptor channels: diversity by RNA editing. Neuron 10:491-500.
Koltchine V, Anantharam V, Wilson A, Bayley H, Treistman SN (1993) Homomeric assemblies of NMDAR 1 splice variants are sensitive to ethanol. Neurosci Lett 152:13-16.

Legendre P, Rosenmund C, Westbrook GL (1993) Inactivation of NMDA channels in cultured hippocampal neurons by intracellular calcium. J Neurosci 13:674-684.

Lovinger DM (1993) High ethanol sensitivity of recombinant AMPAtype glutamate receptors expressed in mammalian cells. Neurosci Lett 159:83-87.

Lovinger DM, White G, Weight $\Gamma \Gamma$ (1989) Ethanol inhibits NMDAactivated ion current in hippocampal neurons. Science 243:17211724.

Machu TK, Olsen RW, Browning MD (1991) Ethanol has no effect on cAMP-dependent protein kinase-, protein kinase $\mathrm{C}$-, or $\mathrm{Ca}^{2+}$-calmodulin-dependent protein kinase II-stimulated phosphorylation of highly purified substrates in vitro. Alcohol Clin Exp Res 15:1040-1044.

Masood K, Wu C, Brauneis U, Weight FF (1994) Differential ethanol sensitivity of recombinant $N$-methyl-D-aspartate receptor subunits. Mol Pharmacol 45:324-329.

McGlade-McCulloh E, Yamamoto H, Tan S-E, Brickey DA, Soderling TR (1993) Phosphorylation and regulation of glutamate receptors by calcium/calmodulin-dependent protein kinase II. Nature 362:640642.

Mishina M, Sakimura K, Mori H, Kushiya E, Harabayashi M, Uchino S, Nagahari K (1991) A single amino acid residue determines the $\mathrm{Ca}^{2+}$ permeability of AMPA-selective glutamate receptor channels. Biochem Biophys Res Commun 180:813-821.

Nakanishi N, Schneider NA, Axel R (1990) A family of glutamate receptor genes: evidence for the formation of heteromultimeric receptors with distinct channel properties. Neuron 5:569-581.

Ozawa S, Iino M, Tsuzuki K (1991) Two types of kainate response in cultured rat hippocampal neurons. J Neurophysiol 66:2-11.

Przywara DA, Chowdhury PS, Bhave SV, Wakade TD, Wakade AR (1993) Barium-induced exocytosis is due to internal calcium release and block of calcium efflux. Proc Natl Acad Sci USA 90:557-561.

Sakimura K, Morita T, Kushiya E, Mishina M (1992) Primary structure and expression of the $\gamma^{2}$ subunit of the glutamate receptor channel selective for kainate. Neuron 8:267-274.

Sanna E, Dildy-Mayfield JE, Harris RA (1994) Ethanol inhibits the function of 5-hydroxytryptamine type 1c and muscarinic $\mathrm{M}_{1} \mathrm{G}$-protein linked receptors in Xenopus oocytes expressing brain mRNA: role of protein kinase C. Mol Pharmacol 45:1004-1012.

Sekiguchi K, Tsukuda M, Ase K, Kikkawa U, Nishizuka Y (1988) Mode of activation and kinetic properties of three distinct forms of protein kinase $C$ from rat brain. J Biochem 103:759-765.

Sigel E, Baur R (1988) Activation of protein kinase C differentially modulates neuronal $\mathrm{Na}^{1}, \mathrm{Ca}^{2}$, and $\gamma$-aminobutyrate type $\mathrm{A}$ channels. Proc Natl Acad Sci USA 85:6192-6196.

Singer D, Boton R, Moran O, Dascal N (1990) Short- and long-term desensitization of serotonergic response in Xenopus oocytes injected with brain RNA: roles for inositol 1,4,5-trisphosphate and protein kinase C. Pfluegers Arch 416:7-16.

Skwish S, Shain W (1990) Ethanol and diolein stimulate PKC translocation in astroglial cells. Life Sci 47:1037-1042.

Slater SJ, Cox KJA, Lombardi JV, Ho C, Kelly MB, Rubin E, Stubbs $C D$ (1993) Inhibition of protein kinase $C$ by alcohols and anaesthetics. Nature 364:82-84.

Snell LD, Tabakoff B, Hoffman PL (1994) Involvement of protein kinase $\mathrm{C}$ in ethanol-induced inhibition of NMDA receptor function in cerebellar granule cells. Alcohol Clin Exp Res 18:81-85.

Sommer B, Seeburg PH (1992) Glutamate receptor channels: novel properties and new clones. Trends Pharmacol Sci 13:291-296.

Sommer B, Köhler M, Sprengel R, Seeburg PH (1991) RNA editing in brain control a determinant of ion flow in glutamate-gated channels. Cell 67:11-19.

Teichberg VI, Tal N, Goldberg O, Luini A (1984) Barbiturates, alcohols and the CNS excitatory neurotransmission: specific effects on the kainate and quisqualate receptors. Brain Res 291:285-292.

Wafford KA, Whiting PJ (1992) Ethanol potentiation of $\mathrm{GABA}_{\mathrm{A}}$ receptors requires phosphorylation of the alternatively spliced variant of the gamma 2 subunit. FEBS Lett 313:113-117.

Wafford KA, Dunwiddie TV, Harris RA (1989) Calcium-dependent chloride currents elicited by injection of ethanol into Xenopus oocytes. Brain Res 505:215-219.

Werner P, Voigt M, Keinänen K, Wisden W, Seeburg PH (1991) Cloning of a putative high-affinity kainate receptor expressed predominantly in hippocampal CA3 cells. Nature 351:742-744. 